\title{
Globalization, the Underserved, and Poverty: An Interactive and Deadly Triad
}

This issue of the fournal of the American Board of Family Medicine ( $7 A B F M)$ is our dedicated Global Theme Issue on Poverty and Human Development, in which $7 A B F M$ is participating in an international collaboration with more than 230 journals that have agreed to a common online release date of October 22, 2007. The Global Theme Issue initiative is organized by the Council of Science Editors, and a complete list of participating journals is on its Web site (http://www.councilscienceeditors.org/ globalthemeissue.cfm). With the common release date, science journals throughout the world will simultaneously publish papers to raise awareness of and to stimulate interest and research into poverty and human development.

Global health is increasingly recognized as vividly important, dramatized by the recent crosscountry hunt for drug-resistant tuberculosis, the large emotional and economic consequences of mad cow disease, the frequency with which we see patients with diseases originating in other countries, and the contamination of food and goods.

Local to global health results from increased international travel and advancing technology and is increasingly known through the efforts of the media. Global health effects result from many factors, including cultural customs, the interaction of local history and conditions, and various economic and governmental systems. Lack of sufficient and appropriate food, lack of medical care, and other poverty-related concerns dominate in many global health issues as problems in one area or locale rapidly can become world-wide tragedies.

This issue of $7 A B F M$ includes commentaries, special communications, research articles, and a personal story. Starfield, ${ }^{1}$ who has conducted much important research on the organization and delivery of service, eloquently reminds us of just how important the organization and availability of primary care is for improving health throughout the world, including the United States (which often seems to have forgotten this important fact):
"Multi-morbidity is demanding not 'chronic disease' management, but rather, a chronic care model in which person-focused primary care is the key element." Starfield argues against excessive intervention, too much focus on hospital-based training, and argues for greater comprehensiveness of training.

Montegut et $\mathrm{al}^{2}$ notes that the World Health Organization, ostensibly about improving the health of the world, has tended to be too vertically focused on individual diseases rather than focusing horizontally on improving needed primary care. Beasley et $\mathrm{al}^{3}$ further notes that "Primary health care is equity-producing." They advocate for primary care practice-based research as essential to maximally improve health care globally. Improving the primary health care infrastructure also requires resources along with organizational know-how, plus education for and involvement of clinical practitioners. These 3 authors ${ }^{1,2,3}$ challenge our international organizations to aggressively commit to improving both primary health care and its research.

Within the United States, incorporation of community health science into academic family medicine could help improve the health disparities, as noted by DeHaven and Gimpel. ${ }^{4}$ Most premature death is related to lifestyle, behavior, environment, and access to care issues. Primary, secondary, and tertiary prevention should be integrated into our communities with our academic institutions as key drivers. Practice-based research and strong advocacy at the national level are the next steps.

At the specific level, Planta ${ }^{5}$ reviews the evidence that poverty plays a significant role in the development of antimicrobial resistance and provides 5 recommendations for improvement. Although this is well known and studied in developing countries, the same is probably also true in the United States. Resistant bacteria is both imported and created in the United States through inadequate availability or use of the correct and complete 
antibiotic courses. Use of leftover antibiotics and use of antibiotics for inappropriate infections, such as viral upper respiratory infections, is common. Almost a quarter of patients in one study in an urban US environment got their antibiotics from somewhere other than a formal prescription. In addition to antimicrobial resistance, tuberculosis is another of the global international infectious scourges. Madariaga et $\mathrm{al}^{6}$ reviews the newer blood tests for tuberculosis, including test characteristics in different types of patient populations.

We also have examples of international practicebased research. We have 2 papers from The Netherlands, a country with a strong tradition of primary care research. Soeteman et $\mathrm{al}^{7}$ consider the types of health problems that increase after a disaster, and the predictors thereof, as found in family medicine offices providing continuity of care before and after the disaster. This may have increased importance in an age of terrorism. Van Gerwen et $\mathrm{al}^{8}$ used a case control methodology to identify specific comorbid conditions associated with incontinence in over 1700 patients and 4000 controls.

In addition to traditional physician care, Israel has many complementary and alternative medicine providers, similar to various other countries. BenArye et $\mathrm{al}^{9}$ explored the viewpoints of both types of practitioners on their potential interactions; needless to say they found some agreement and some disagreement.

To further family medicine education internationally, Saunders ${ }^{10}$ provides an example from the Republic of Georgia of one type of family medicine training program that proved successful in improving care and doing so in a cost-efficient manner.

Incredibly, health disparities exist within a rich country such as the United States. Fiscella et al ${ }^{11}$ investigated disparities for the receipt of preventive care by African Americans. They report that the number of primary care visits is very important to receipt of services, and that the key characteristic determining receipt of preventive services is poverty, not ethnicity. Cadzow et $\mathrm{al}^{12}$ found that individuals who come to a student-run free medical clinic were mostly uninsured and had many medical problems in need of significant amounts of ongoing chronic disease health care. Hicks et $\mathrm{al}^{13}$ report that reminder cards can be useful to increase immunization rates among Latinos and the rural poor. Further, Mainous et $\mathrm{al}^{14}$ remind us that in the United States, Latinos and Hispanics from differ- ent cultural contexts should not be lumped together because of significant differences in how they receive care.

Finally, on the other end of the spectrum, Elder ${ }^{15}$ keeps us grounded with a personal and poignant story of cross-national adoption.

We believe it important to participate in the international collaboration with this $7 A B F M$ Global Theme Issue to demonstrate interest in and raise awareness of international health issues. Readers are also encouraged to read in this issue the Editors' Note, ${ }^{16}$ which provides additional information related to $7 A B F M$ 's international activities and commitment.

Marjorie A. Bowman, MD, MPA, Editor Anne Victoria Neale, PhD, MPH, Deputy Editor

\section{References}

1. Starfield B. Global health, equity, and primary care. J Am Board Fam Med 2007;20(6):511-513.

2. Montegut AJ. To achieve "health for all" we must shift the world's paradigm to "primary care access for all." J Am Board Fam Med 2007;20(6):514-517.

3. Beasley JW, Starfield B, van Weel C, Rosser WW, Haq CL. Global health and primary care research. J Am Board Fam Med 2007;20(6):518-526.

4. DeHaven MJ, Gimpel NE. Reaching out to those in need: the case for community health science. J Am Board Fam Med 2007;20(6):527-532.

5. Planta MB. The role of poverty in antimicrobial resistance. J Am Board Fam Med 2007;20(6):533-539.

6. Madariaga MG, Jalali Z, Swindells S. Clinical utility of interferon gamma assay in the diagnosis of tuberculosis. J Am Board Fam Med 2007;20(6):540-547.

7. Soeteman RJH, Yzermans CJ, Kerssens JJ, et al. Health problems presented to family practices in The Netherlands 1 year before and 1 year after a disaster. J Am Board Fam Med 2007;20(6):548-556.

8. van Gerwen M, Schellevis F, Lagro-Janssen T. Comorbidities associated with urinary incontinence: a case-control study from the Second Dutch National Survey of General Practice. J Am Board Fam Med 2007;20(6):608-610.

9. Ben-Arye E, Scharf M, Frenkel M. How should complementary practitioners and physicians communicate? A cross-sectional study from Israel. J Am Board Fam Med 2007;20(6):565-571.

10. Sanders J. A family medicine training program in the Republic of Georgia: incorporating a model of chronic disease management. J Am Board Fam Med 2007;20(6):557-564.

11. Fiscella K, Holt K. Impact of primary care patient visits on racial and ethnic disparities in preventive care in the United States. J Am Board Fam Med 2007;20(6):587-597. 
12. Cadzow RB, Servoss TJ, Fox CH. The health status of patients of a student-run free medical clinic in inner-city Buffalo, NY. J Am Board Fam Med 2007; 20(6):572-580.

13. Hicks P, Tarr GAM, Prieto Hicks X. Reminder cards and immunization rates among Latinos and the rural poor in northeast Colorado. J Am Board Fam Med 2007;20(6):581-586.

14. Mainous AG, Diaz VA, Saxena S, Geesey ME. Het- erogeneity in management of diabetes mellitus among Latino ethnic subgroups in the United States. J Am Board Fam Med 2007;20(6):598-605.

15. Elder NC. Almost 9: a personal essay on parenting, aniridia, and being a doctor. J Am Board Fam Med 2007;20(6):606-607.

16. Neale AV, Bowman MA. Information for our international colleagues. J Am Board Fam Med 2007; 20(6):510. 